Vol. 2, No. 04; 2019

ISSN: 2581-4664

\title{
MONETARY AND FISCAL POLICIES ON INFLATION: EVIDENCE FROM PRE- CRISIS AND POST-CRISIS PERIODS IN THAILAND
}

\author{
Chai-Thing Tan ${ }^{1}$ and Azali Mohamed ${ }^{2}$ \\ ${ }^{1}$ Faculty of Business and Finance,Tunku Abdul Rahman University, Malaysia \\ ${ }^{2}$ Faculty of Economics and Management, University Putra Malaysia, Malaysia
}

http://doi.org/10.35409/IJBMER.2019.2411

\begin{abstract}
The purpose of this study is to examine the long-run relationship monetary and fiscal policy on inflation in Thailand by employing an Autoregressive Distributed Lag (ARDL). This study uses quarterly data from 1980: Q1 to 2017:Q1 and divides the sample data into pre-crisis period (1980Q1-1997Q3) and post crisis period (1997Q4-2017Q1). The results revealed that the longrun relationship between government spending and inflation was positive. The results implied that government spending was one of the important components when determining the inflation. However, interest rate was positive in pre-crisis and negative in post-crisis. The results indicated that monetary policy is more effective on inflation in the post-crisis period. Both pre- crisis and post-crisis period show that fiscal policy is more effective in influencing the inflation in Thailand. These results suggest that inflation in Thailand inflation is highly sensitive to the change in monetary and fiscal policies, especially as it emerges from a financial crisis.
\end{abstract}

Keyword: Monetary policy, Fiscal policy, ARDL.

\section{JEL Classification: E52, E62}

\section{INTRODUCTION}

The main objective of the monetary policy is to maintain price stability. Thus, the determinant of the inflation is an important issue and it draws a lot of interest of both policymakers and monetary authorities. Monetarist's claimed that inflation is always a monetary phenomenon, thus, the government spending will not affect the price. However, according to the fiscal theory of price level, fiscal policy is important. It is often argued that inflation is cause by the monetization of budget deficits especially in developing countries (Tekin-Koru and Özmen, 2003). Thus, fiscal policy could be one of the sources of the inflation. There is no clear answer that whether monetary or fiscal policy has significant impact on inflation. Further, the effectiveness of monetary and fiscal policy on inflation is likely to be affected by external events such as the 1997 Asian Financial Crisis. This is because shocks from such events may have depressing effects on the entire economy including the price level.

However, there is less studies focus on Asian countries such as Thailand. The inflation in Thailand has remained remarkably low and stable after 1980s. As shown in Figure 1, there has been a marked decline in the inflation during the crisis period. Thus, this paper aims to 


\section{International Journal of Business Management and Economic Review}

Vol. 2, No. 04; 2019

ISSN: 2581-4664

answering the following three questions: (1) Does monetary policy affect the inflation? (2) Does fiscal policy affect the inflation? And (3) Does crisis change the effectiveness of monetary or fiscal policy on inflation?

Figure 1 Thailand's Consumer Price Index (2010=100), 1980-2018

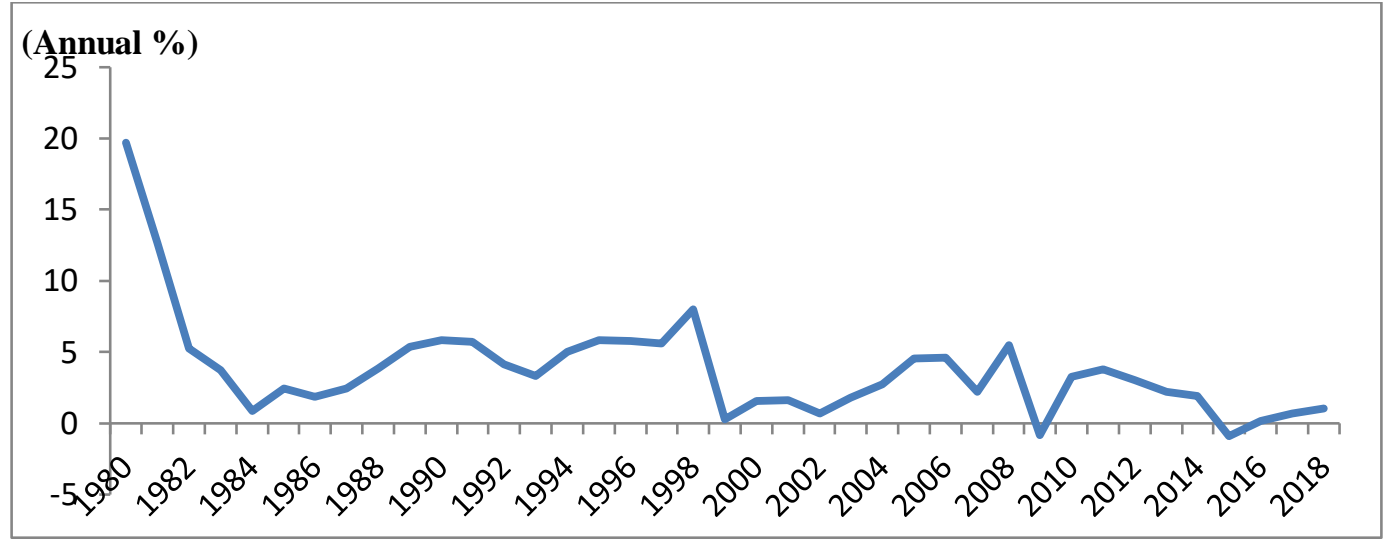

The purpose of this paper is twofold. Firstly, to examine the long-run relationship among inflation, interest rate and government spending in Thailand and secondly, to examining the impact of monetary and fiscal policy on inflation pre- and post-crisis. The rest of the paper is organized into five sections. Section 2 reviews the literature, Section 3 describes the methodology and model specification. Section 4 discusses the data and empirical results. Section 5 concludes.

\section{EMPIRICAL EVIDENCE ON THE RELATIONSHIP BETWEEN THE MONETARY POLICY, FISCAL POLICY AND INFLATION}

Fiscal policy has been proven to have a positive impact on inflation in a number of studies, such as the case of Greece (Shabbir, Ahmed \& Ali, 1994) and developing countries (Darrat, 2000; Narayan \& Narayan, 2006; Habibullah, Cheah \& Baharom, 2011; Jalil, Tariq \& Bibi, 2014). In contrast, Karras (1994) found that a fiscal deficit has no inflationary impact. This discovery was consistent with Cottarelli, Griffiths and Moghadam (1998) who focused on industrial and transition economies. Meanwhile, Fischer, Sahay and Végh (2002) and Lin and Chu (2013) revealed that a fiscal deficit was only effective during periods of high inflation, this was supported by Catao and Terrones (2005) who studied high-inflation or developing countries.

Some studies have highlighted the importance of monetary policy on the price level. Research carried out by Cioran (2014), Yunana, Michael and Akpan (2015) and Adedamola (2015) found a negative effect of the interest rate on inflation. A common price puzzle was found in empirical studies. This price puzzle refers to a positive interest rate shock leading to an initial increase in the price level, rather than a reduction (Sims, 1992; Christiano, Eichenbaum \& Evans, 1994; Balke \& Emery, 1994). Furthermore, the research studies by Arin and Jolly (2005) covering Australia and New Zealand and Perera (2016) for Sri Lanka also showed a positive relationship 


\section{International Journal of Business Management and Economic Review}

Vol. 2, No. 04; 2019

ISSN: 2581-4664

between the interest rate and inflation. Several studies have included other variables, such as commodity prices (Hanson, 2004) or the output gap (Bonga-Bonga \& Kabundi, 2011) in order to overcome the problem of the price puzzle. However, the price puzzles still remain unsolved.

Policy coordination is important in dealing with recessions and financial crises. Freedman et al., (2009) showed that appropriate policy coordination could prevent an economy from experiencing further economic downturns, even during a deep recession and deflation. Besides that, Hutchison, Noy and Wang (2010) concluded that fiscal expansion was more effective than monetary expansion in emerging and developing economies when dealing with financial crises, this result was consistent with that of the study by Fetai (2013).

Notwithstanding, the impact of policy coordination on the price level is another concern of researchers. Mahmood and Sial (2011) discovered that fiscal policy was more dominant in affecting prices when compared to monetary policy. Meanwhile, Van (2014) found that both monetary and fiscal policies had no effect on the real GDP, however, monetary policy had a stronger effect on the price level. Tekin-Koru and Özmen (2003) found that monetary growth had a positive impact while budget deficit had a no effect on inflation in the case of Turkish. The findings of Tekin-Koru and Özmen (2003) were similar with Khieu (2014) in Vietnem and Mukhtar and Zakaria (2010) in Pakistan. By investigating the granger causality effects of these two policies on inflation, Lozano-Espitia (2008) discovered that budget deficit granger cause monetary growth and subsequently, monetary growth to cause inflation in Colombia.

In all the above mentioned studies, there are lacks empirical work has been carried out in Thailand. Much research has been carried out to analyze the relationship among inflation, monetary and fiscal policies, with mixed results. Most of the studies focus on policy coordination could prevent the economic downturns and deflation, but studies on how effectiveness of monetary and fiscal policy on inflation during financial crises are lack. Further, this study intends to contribute to the literature by examining the impact of monetary and fiscal policy on inflation by compare the effect before and after crisis. Therefore, there is a need to re-estimate the issue.

\section{METHODOLOGY}

\section{Model specification}

This paper employs the ARDL modeling to estimate the impact of monetary and fiscal policy on inflation. The main reasons to apply this methodology are this approach regardless of the stationary properties of the variables such as $\mathrm{I}(0)$ or $\mathrm{I}(1)$.

The model of inflation following Bayo $(2011)^{1}$, the general model is specified as follows:

$P=f(M M R, G, R E E R)$

(1)

1 This study does not included the money supply from the work of Bayo (2011) because Thailand adopts inflation targeting and used the interest rate as their main monetary instrument (Chow, Lim \& McNelis, 2014) 


\section{International Journal of Business Management and Economic Review}

Vol. 2, No. 04; 2019

ISSN: 2581-4664

Where $\mathrm{P}$ is consumer price index as a proxy for inflation, MMR is the money market rate as a proxy for monetary policy, $\mathrm{G}$ is government spending as proxy of fiscal policy and REER is exchange rate.

Equation (1) stated econometrically as

$P_{t}=\beta_{0}+\beta_{1} M M R_{t}+\beta_{2} G_{t}+\beta_{3} R E E R_{t}+u_{t}^{P}$

The sign of $\beta_{1}$ and $\beta_{3}$ are expected to be negative while the sign of $\beta_{2}$ is expected to be positive. Increase in interest rate will increase the cost of borrowing result less people borrow money or spend. Thus, cause the inflation decrease. Researches carried out by Cioran (2014), Yunana, Michael and Akpan (2015) and Adedamola (2015) found interest rate and inflation are negative relationship. An increase in exchange rate (appreciate) will decrease the net export cause the input price and wages drop, so exchange rate and inflation are negative relation. This is found in Monfared and Akin (2017) and Takhtamanova (2010). The higher the government spending will lead to the demand-pull inflation (Shabbir, Ahmed \& Ali, 1994; Darrat, 2000; Narayan \& Narayan, 2006; Habibullah, Cheah \& Baharom, 2011; Jalil, Tariq \& Bibi, 2014).

The ARDL framework of equation 2 can be written as:

$$
\Delta P_{t}=\beta_{0}+\beta_{1} M M R_{t-1}+\beta_{2} G_{t-1}+\beta_{3} \operatorname{REER}_{t-1}+\sum_{i=1}^{p} \gamma_{1 i} \Delta Y_{t-i}+\sum_{i=0}^{q} \gamma_{2 i} \Delta M M R_{t-i}+\sum_{i=0}^{r} \gamma_{3 i} \Delta G_{t-i}+\sum_{i=0}^{s} \gamma_{4 i} \Delta R E E R_{t-i}+u_{t}^{Y}
$$

Where $\Delta$ refers to the first-difference operator, $p, q, r$ and $s$ refers to the optimum lag length uses in the model.

\section{DATA AND EMPIRICAL RESULTS}

\subsection{Data and preliminary analysis}

This study uses quarterly data from 1980: Q1 to 2017:Q1 to capture the effects of policies on inflation. To test whether the results of the estimated coefficients statistically differ across the pre-crisis and post-crisis, the data is divided into pre-crisis period (1980Q1-1997Q3) and postcrisis period (1997Q4-2017Q1). We apply the Chow test and it confirms the existence of a structure change between the examined periods. The variables included in the ARDL model are as follow: 1) real GDP $\left(\mathrm{Y}_{\mathrm{t}}\right)$, which is used to capture the economic activity; 2) money market rate $\left(M_{M}\right)$, which is used to capture the monetary policy stance; 3 ) government spending $\left(G_{t}\right)$, which is used as the fiscal policy instruments. 4) Exchange rate (REER) is real effective exchange rate based on CPI $(2010=100)$. It reflects the aggregate behaviour of the major currencies of the countries' main trading partners. So an increase in the REER indicates that the real appreciation of the domestic currency. All the variables are showed in natural logarithms 


\section{International Journal of Business Management and Economic Review}

Vol. 2, No. 04; 2019

ISSN: 2581-4664

except interest rates. All time-series involved in this study are adjusted from seasonality. The source of data is Datastream.

Table 1 ADF and PP Unit Root Tests

\begin{tabular}{|c|c|c|c|c|}
\hline \multirow[b]{2}{*}{ Variable } & \multicolumn{2}{|c|}{$\begin{array}{c}\text { Level } \\
\text { Intercept and trend }\end{array}$} & \multicolumn{2}{|c|}{$\begin{array}{c}\text { First difference } \\
\text { Intercept and trend }\end{array}$} \\
\hline & ADF & $\mathbf{P P}$ & ADF & $\mathbf{P P}$ \\
\hline \multicolumn{5}{|c|}{ 1980Q1-2017Q1 } \\
\hline $\mathrm{P}$ & $-0.58(13)$ & $-1.79(7)$ & $-3.47(13)^{* * *}$ & $-9.82(5) * * *$ \\
\hline MMR & $-4.37(3) * * *$ & $-3.63(2)^{* * *}$ & $-4.76(12) * * *$ & $-9.98(4) * * *$ \\
\hline G & $-1.96(13)$ & $-9.91(10)^{* * *}$ & $-5.41(7) * * *$ & $-31.70(12)^{* * *}$ \\
\hline REER & $-1.93(5)$ & $-2.12(7)$ & $-6.47(4)^{* * *}$ & $-8.90(12)^{* * *}$ \\
\hline \multicolumn{5}{|c|}{ 1980Q1-1997Q3 } \\
\hline $\mathrm{P}$ & $-1.8107(11)$ & $-2.7674(5)$ & $-4.1273(4) * * *$ & $-7.6235(0) * * *$ \\
\hline MMR & $-1.8087(0)$ & $-1.7121(2)$ & $-6.9439(1)^{* * *}$ & $-7.7938(1)^{* * *}$ \\
\hline $\mathrm{G}$ & $-0.9268(7)$ & $-2.2584(1)$ & $-4.0301(5)^{* * *}$ & $-13.8373(5) * * *$ \\
\hline REER & $-2.3060(4)$ & $-1.7739(1)$ & $-5.1703(0) * * *$ & $-4.8126(3)^{* * *}$ \\
\hline \multicolumn{5}{|c|}{ 1997Q4-2017Q1 } \\
\hline $\mathrm{P}$ & $-2.9249(11)$ & $-1.5098(3)$ & $-4.6315(4) * * *$ & $-6.1589(22) * * *$ \\
\hline MMR & $-6.4891(11) * * *$ & $-3.9866(4) * *$ & $-7.5649(10)^{* * *}$ & $-6.9625(4)^{* * *}$ \\
\hline G & $-8.5605(0) * * *$ & $-8.5605(2)^{* * *}$ & $-6.4829(5)^{* * *}$ & $-24.6444(22) * * *$ \\
\hline REER & $-3.1122(9)$ & $-3.7916(0) * *$ & $-4.3923(7) * * *$ & $-11.3961(14)^{* * *}$ \\
\hline
\end{tabular}

Note: the numbers in parentheses are the lag order in the ADF test. The lag parameters are selected based on the AIC. Truncation lags are used for the Newey-West correction of the PP test in parentheses. $* * *, * * *$ indicates significance at the $1 \%, 5 \%$ and $10 \%$ level.

ARDL approach does not require the variables to have the same order of integration (e.g I(0) or $\mathrm{I}(1)$ but the variable cannot presence the order of I(2). Given that bound test procedure can not include I(2) variables, Augmented Dickey-Fuller (ADF) tests and Phillips-Perron (PP) tests unit root tests are used to determine the stationary of the variables. The results are reported in Table 1. In the test we include both constant and trend terms and employ the AIC for select optimal lag order in $\mathrm{ADF}$ test equation.

In the full sample (1980Q1-2017Q1), both ADF and PP test show that only interest rate is integrated of order 1 with significant of 5 percent. In the pre-crisis sample (1980Q1-1997Q3), both ADF and PP test show that all variables are integrated of order 1 with significant of 5 percent. However, in the post-crisis sample (1997Q4-2017Q1), both ADF and PP test show that interest rate and government spending are integrated of order 1 . Since both test show that none of the variables is $\mathrm{I}(2)$, we proceed to examine the presence the long run relationship among the variables. 


\subsection{ARDL}

Table 2 shows that equation (1) rejected the null hypothesis of no cointegration among the variables. The maximum lag is determined using the Akaike Information Criterion (AIC). Based on the Table 2, the results concluded that there is a long-run relationship of monetary and fiscal policies on inflation in 5\% at all three samples. The values of F-statistics in full sample (1980Q12017Q1) (11.11), in the pre-crisis sample (1980Q1-1997Q3) (6.3) and post-crisis sample (1997Q4-2017Q1) (4.64) are found to be greater than upper bound (3.67). This test result suggests that there exists a long run relationship between P, MMR, G and REER for Thailand. Given the existence of cointegration, the long-run coefficients are estimate.

Table 3 shows the results of the estimate equation (2). For each sample, the results have been reported in two Panels. Panel A and B show the long-run normalized estimated coefficients and error correction term. The t-statistics of each variable are show in parenthesis.

Table 2 Bounds Test

\begin{tabular}{|ccc|}
\hline $\begin{array}{c}\text { Model specification } \\
P=f(M M R, G, R E E R)\end{array}$ & F-statistic & Conclusion \\
\hline 1980Q1-2017Q1 & $11.11(3) * * *$ & cointegration \\
1980Q1-1997Q3 & $6.30(3) * * *$ & cointegration \\
1997Q4-2017Q1 & $4.64(3) * *$ & cointegration \\
\hline \hline
\end{tabular}

Table 3 ARDL estimation results

\section{Panel A: Estimated long-run coefficient}

\begin{tabular}{|c|c|c|c|}
\hline Variables & $\begin{array}{c}1980 \mathrm{Q} 1-2017 \mathrm{Q} 1 \\
(3,0,3,1)^{\mathrm{a}}\end{array}$ & $\begin{array}{c}1980 \mathrm{Q} 1-1997 \mathrm{Q} 3 \\
(3,0,3,1)^{\mathrm{b}}\end{array}$ & $\begin{array}{c}1997 \mathrm{Q} 4-2017 \mathrm{Q} 1 \\
(7,4,4,4)^{\mathrm{c}}\end{array}$ \\
\hline \multirow{2}{*}{ MMR } & 0.0120 & 0.0159 & -0.0070 \\
& $(1.91)^{*}$ & $(2.51)^{* *}$ & $0.07)^{* *}$ \\
\hline \multirow{2}{*}{$\mathrm{G}$} & 0.5663 & 0.5051 & $(11.59)^{* * *}$ \\
& $(18.47)^{* * *}$ & -0.5088 & 0.3437 \\
\multirow{2}{*}{ REER } & -0.3478 & $(-3.36)^{* * *}$ & $(2.78)^{* * *}$ \\
\hline \multirow{2}{*}{$\mathrm{C}$} & $(-2.76)^{* * *}$ & 3.8594 & 0.6474 \\
& 2.9109 & $(5.06)^{* * *}$ & $(1.67)$ \\
\hline \multicolumn{2}{|c|}{ Panel B: Error correction term } & -0.0846 & -0.2474 \\
\hline \multirow{2}{*}{ ECT (t-1) } & -0.0578 & $(-6.28)^{* * *}$ & $(-4.99)^{* * *}$ \\
\hline
\end{tabular}

Note: a,b,c refer to the ARDL selected based on Akaike Information Criterion. Figures in parenthesis are t-statistic, *,**, and $* * *$ denote significant at $10 \%, 5 \%$ and $1 \%$ levels, 


\section{International Journal of Business Management and Economic Review}

Vol. 2, No. 04; 2019

ISSN: 2581-4664

respectively.

In the full sample, the coefficient of the interest rate was statistically significant and positive to inflation. This scenario is known as the price puzzle. Barth and Ramey (2000) suggested that monetary policy operates through both demand and supply effects may cause price increase. This is consistent with Arin and Jolly (2005). The coefficient of government spending is positive and statically significant. This is a fiscal phenomenon (Shabbir et al., 1994). The exchange rate shows a statistically negative effect on inflation were consistent with Monfared and Akin (2017) who found appreciated exchange rate caused deflation due to the domestic product is more expensive for foreigner. This cause the total export and demand drop and lead to deflation.

By compare pre- and post-crisis, it is clear that the monetary policy play a role in inflation. The coefficient of interest rate is positive and statistically significant before crisis and it turn to negative after the financial crisis. This indicated that the monetary policy is more effective on inflation in the period after the financial crisis. The government spending was statistically positive to inflation in both pre-crisis and post-crisis, there had no statistically differ. This indicated that the fiscal policy is effective on inflation in both the periods. Our result suggests that monetary and fiscal policies could prevent an economy for further deflation. The results were consistent with Hutchison, Noy and Wang (2010) and Fetai (2013) that the fiscal expansion was more effective than monetary expansion when dealing with financial crises.

Similar with full sample, the estimated coefficient of exchange rate had a statistically significant negative effect on inflation in the pre-crisis periods. In contrast, in post-crisis periods, it changed to positive effect. The result shows that weak global demand can dampen the effect of exchange rate on inflation.

The $\mathrm{ECT}_{\mathrm{t}-1}$ terms were statistically significant in negative. This implies the speed of adjustment take approximately 3 years in pre-crisis and 1 year in post-crisis Thailand to converge back to the equilibrium path. CUSUM and CUSUMSG statistics in Table 4 shows it is well within the critical bounds which showed that all the coefficients in the model were constant.

Table 4 CUSUM test and CUSUM of Squares test

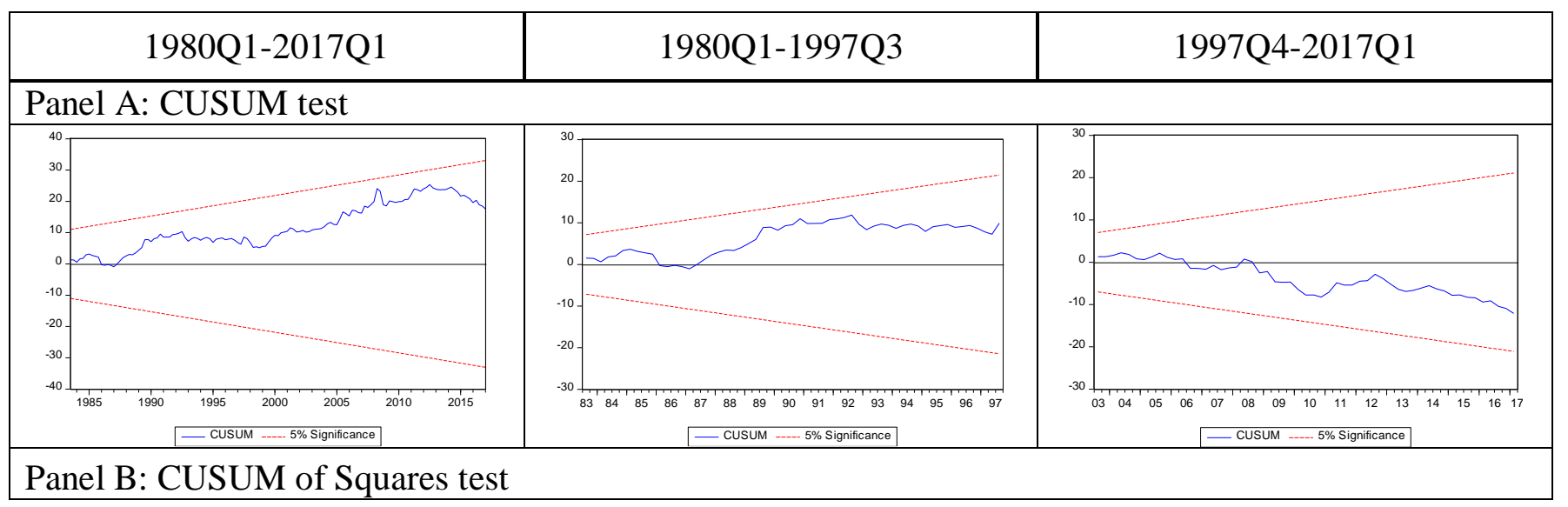




\section{International Journal of Business Management and Economic Review}

Vol. 2, No. 04; 2019

ISSN: 2581-4664

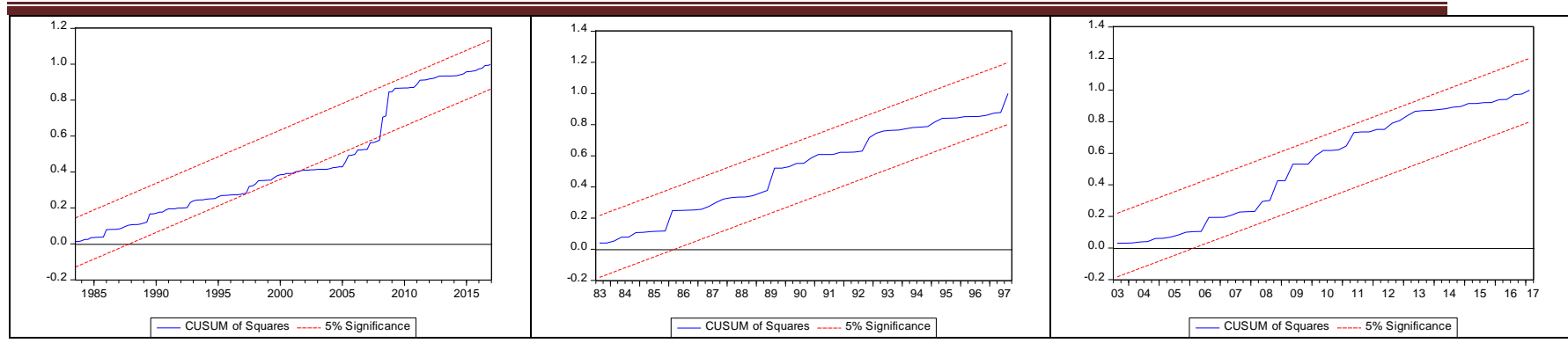

\section{CONCLUSION}

This paper examines the long-run relationship of monetary and fiscal policy on inflation in Thailand. This study uses quarterly data from 1980: Q1 to 2017:Q1 and divides the sample data into pre-crisis period (1980Q1-1997Q3) and post crisis period (1997Q4-2017Q1). The results revealed that the long-run relationship between government spending and inflation was positive regardless of pre-crisis or post-crisis periods. The results implied that government spending was one of the important components when determining the inflation. However, interest rate was positive in pre-crisis and negative in post-crisis periods. The results indicated that monetary policy is more effective on inflation in the post-crisis period. Both pre-and post-crisis period show that fiscal policy is more effective in influencing the inflation in Thailand. The empirical results show there is a remarkable difference in the pre-crisis and post-crisis policies performance on inflation. These results suggest that inflation in Thailand is highly sensitive to the change in monetary and fiscal policies, especially as it emerges from a financial crisis.

\section{REFERENCES}

Adedamola, S. L. (2015). An empirical analysis of price stability effect of Nigerian monetary policy (1981-2012). Public and Municipal Finance, 4(1), 37-42.

Arin, K. P., \& Jolly, S. (2005). Trans-tasman transmission of monetary shocks: Evidence from a VAR Approach. Atlantic Economic Journal, 33(3), 267-283.

Balke, N. S., \& Emery, K. M. (1994). Understanding the price puzzle. Federal Reserve Bank of Dallas Economic Review, Fourth Quarter, 15-26.

Barth III, M. J., \& Ramey, V. A. (2001). The cost channel of monetary transmission. NBER Macroeconomics Annual, 16, 199-240.

Bayo, F. (2011). Determinants of inflation in Nigeria: An empirical analysis. International Journal of Humanities and social science, 1(18), 262-271.

Bonga-Bonga, L., \& Kabundi, A. (2011). Monetary policy action and inflation in South Africa: an empirical analysis. African Finance Journal, 13(2), 25-37.

Catao, L. A., \& Terrones, M. E. (2005). Fiscal deficits and inflation. Journal of Monetary Economics, 52(3), 529-554.

Chow, H. K., Lim, G. C., \& McNelis, P. D. (2014). Monetary regime choice in Singapore: Would a Taylor rule outperform exchange-rate management? Journal of Asian Economics, 30, 63-81.

Christiano L.J., Eichenbaum, M and Evans, C. (1994). The effects of monetary policy shocks: Evidence from the flow of funds. The Review of Economics and Statistics, 78(1),16-34. 


\section{International Journal of Business Management and Economic Review}

Vol. 2, No. 04; 2019

ISSN: 2581-4664

Cioran, Z. (2014). Monetary policy, inflation and the causal relation between the inflation rate and some of the macroeconomic variables. Procedia Economics and Finance, 16, 391-401.

Cottarelli, C., Griffiths, M. \& Moghadam, R. (1998). The nonmonetary determinants of inflation: A panel data study. IMF Working Paper, No. 98/23

Darrat, A. F. (1984). The dominant influence of fiscal actions in developing countries, Eastern Economic Journal, 10(3), 271-284.

Fetai, B. T. (2013). Monetary and fiscal responses during the financial crisis in the developing and emerging economies. International Journal of Economics and Finance, 5(9), 110-116.

Fischer, S., Sahay, R., \& Végh, C. A. (2002). Modern hyper-and high inflations. Journal of Economic literature, 40(3), 837-880.

Freedman, C., Kumhof, M., Laxton, D., \& Lee, J. (2009). The Case for Global Fiscal Stimulus. IMF Staff Position Note. 09/03. Washington, DC. International Monetary Fund (IMF).

Habibullah, M. S., Cheah, C. K., \& Baharom, A. H. (2011). Budget deficits and inflation in thirteen Asian developing countries. International Journal of Business and Social Science, 2(9), 192-204.

Hanson, M. S. (2004). The "price puzzle" reconsidered. Journal of Monetary Economics, 51(7), 1385-1413.

Hutchison, M., Noy, I., \& Wang, L. (2010). Fiscal policy and monetary policy and the cost of sudden stops. Journal of International Money and Finance. 30, 1-15.

Jalil A,. Tariq, R., \& Bibi, N (2014). Fiscal deficit and inflation: New evidences from Pakistan using a bounds testing approach. Economic Modelling, 37, 120-126

Karras, G. (1994). Macroeconomic effects of budget deficits: further international evidence. Journal of International Money and Finance, 13(2), 190-210.

Khieu, H. (2014). Budget deficit, money growth and inflation: Empirical evidence from Vietnam. MPRA Paper, 54488.

Lin, H. Y., \& Chu, H. P. (2013). Are fiscal deficits inflationary?. Journal of International Money and Finance, 32, 214-233.

Lozano-Espitia, L. I. (2008). Budget deficit, money growth and inflation: evidence from the Colombian case. Borradores de Economía; No. 537.

Mahmood, T., \& Sial, M. H. (2011). The relative effectiveness of monetary and fiscal policies in economic growth: A case study of Pakistan. Asian Economic and Financial Review, 1(4), 236-244.

Monfared, S. S., \& Akın, F. (2017). The relationship between exchange rates and inflation: The case of Iran. European Journal of Sustainable Development, 6(4), 329-340.

Mukhtar, T., \& Zakaria, M. (2010). Budget Deficit, Money Supply and Inflation: The Case of Pakistan. Economic Trends \& Economic Policy, 20(122).

Narayan, P. K., \& Narayan, S. (2006). Government revenue and government expenditure nexus: evidence from developing countries. Applied Economics, 38(3), 285-291.

Perera, A. (2016). Monetary Transmission Mechanism in Sri Lanka: A Comprehensive Assessment with New Evidence. Staff Studies, 43(1-2), 31-84.

Shabbir, T., Ahmed, A., \& Ali, M. S. (1994). Are government budget deficits inflationary? Evidence from Pakistan. The Pakistan Development Review, 33(4), 955-967.

Sims, C. A. (1992). Interpreting the macroeconomic time series facts: The effects of monetary policy. European economic review, 36(5), 975-1000. 
International Journal of Business Management and Economic Review

Vol. 2, No. 04; 2019

ISSN: 2581-4664

Takhtamanova, Y. F. (2010). Understanding changes in exchange rate pass-through. Journal of Macroeconomics, 32(4), 1118-1130.

Tekin-Koru, A., \& Özmen, E. (2003). Budget deficits, money growth and inflation: the Turkish evidence. Applied Economics, 35(5), 591-596.

Van H.K. (2014). Budget deficit, money growth and inflation: Empirical evidence from Vietnam. (Munich Personal RePEc Archive Paper 54488). University Library of Munich, Germany.

Yunana, T. W., Michael, B., \& Akpan, J. E.(2015). Impact of Monetary Policy on Inflationary Process in Nigeria. European Journal of Business and Management. 7(31),62-68. 